\author{
MARIA GRZYBKOWSKA, JOANNA LESZCZYŃSKA, ŁUKASZ GŁOWACKI
}

Katedra Ekologii i Zoologii Kregowców Wydział Biologii i Ochrony Środowiska

Uniwersytet Łódzki

Banacha 12/16, 90-237 Łódź

E-mail: maria.grzybkowska@biol.uni.lodz.pl

\title{
ZA I PRZECIW OWADOM NA TALERZU
}

\section{PRZYCZYNY I SKUTKI PRZELUDNIENIA - ANTROPOCEN}

Żyjemy w antropocenie, a dokładniej w jego III okresie zwanym Wielkim Przyspieszeniem, który rozpoczął się w latach 50. XX wieku. Nazwę antropocen utworzyli Stoermer (specjalista od glonów, głównie okrzemek) i badacz atmosfery Crutzen (laureat Nagrody Nobla w dziedzinie chemii) (CRUTZEN i STOERMER 2000). Pojęcie to wskazuje na dominujaccy wpływ Homo sapiens na geologię i ekosystemy Ziemi - człowiek stał się hipersprawcza siła modyfikująca równocześnie wiele jej parametrów (ZALASIEWICZ 2016, BIŃCZYK 2017). Zaproponowany termin spotkał się $z$ szerokim aplauzem, zarówno fachowców, jak i laików (KUNDZEWICZ i JUDA-REZLER 2010, PTASZYŃSKA 2019). Paradoksem antropocenu, a szczególnie Wielkiego Przyśpieszenia, jest jednak to, że wynikająca $z$ siły człowieka dominacja nad światem stawia przetrwanie ludzkości pod znakiem zapytania; kiedy jej nie było, człowiek wydawał się dużo mniej zagrożony niż obecnie. W literaturze przedmiotu pojawily się nawet pytania, czy wskutek zachodzacych na planecie zmian ludzkość przetrwa kolejnych 500 lat (CAVEs 2016)? Czy uda nam się uniknać wymarcia (GRINSPOON 2016)?

Nie ulega wątpliwości, że główna przyczyna tego stanu zagrożenia jest przeludnienie Ziemi (GRZYBKOWSKA i LESZCZYŃSKA 2019). Zdaniem wielu badaczy sa trzy główne powody eksplozji liczebności populacji człowieka: ograniczenie chorób dziesiątkujących ludzkość (głównie dzięki szczepieniom), wyeliminowanie głodu i uwolnienie człowieka od ciężkiego wysiłku fizycznego. Coraz gwałtowniejszy wzrost tej liczebności powoduje coraz szybszy wzrost zapotrzebowania na żywność. W celu zaspokojenia tego zapotrzebowania, na coraz większa skale i coraz bardziej bezwzględnymi metodami, hoduje się rośliny i zwierzęta kręgowe, co doprowadza do degradacji środowiska i w konsekwencji do wymierania wielu gatunków (SIENKIEwICZ 2013). Te hodowle i towarzyszace im inwestycje (wzrost uprzemysłowienia) wymagaja ogromnej ilości energii, której głównym źródłem były i sa paliwa kopalne, pomimo programów pozyskiwania jej w coraz większym stopniu ze źródeł odnawialnych.

Dane statystyczne dotyczace aktualnej diety człowieka zaskakuja liczba zabijanych zwierząt. Przeciętny obywatel krajów rozwiniętych zjada $\mathrm{w}$ ciagu swojego życia 11 krów, 27 świń, 30 owiec, 80 indyków, 2400 kurczaków i prawie $4500 \mathrm{~kg}$ ryb, jeśli ograniczymy się tylko do gatunków zwierząt kręgowych od lat wykorzystywanych w celach konsumpcyjnych (DURANDO 2015). Ponadto, wydłużanie przeciętnego trwania życia zwiększa te liczbe $z$ roku na rok, powodujacc intensyfikacje hodowli. Ogromna liczba konsumowanych zwierzat wywołuje rozbudowę i wydłużanie łańcuchów troficznych, co z kolei dokonuje się w wyniku pożerania olbrzymiej masy organizmów, też uprzednio wyprodukowanych i przez to degradujacych środowisko (WilletT i współaut. 2019).

Poza wymienionymi, niezliczone inne gatunki sa okresowo wprowadzane do jadłospisu, włączając te egzotyczne, np. strusie w Polsce. Po latach lub wiekach przerwy, do menu powracają także gatunki, których 
populacje zostały $\mathrm{w}$ przeszłości prawie doszczętnie wyeksploatowane, a obecnie, dzięki podjęciu działań ochronnych, ponownie zwiększyły swoja liczebność. Należy do nich bóbr, a przedmiotem szczególnego pożądania mężczyzn jest jego ogon (w żargonie płetwa), uważany za cenny afrodyzjak. Robert Makłowicz, propagujacy kuchnie różnych narodów świata stwierdził, że jest to jedna $z$ najbardziej obrzydliwych potraw, jakie jadł w swoim życiu. Ale de gustibus non est disputandum. Innym przykładem sa żubry, które od połowy XIX w. krzyżowano $z$ krowami otrzymując żubronie, cechujace się szybkim wzrostem i znacznym ciężarem. Obecnie, zdaniem polskich ministerialnych decydentów, żubry nadmiernie się rozmnożyły, a zatem można je już traktować jak zwierzynę lowna nie wymagajaca krzyżowania $z$ krowami. W podobny sposób, ze względu na odradzanie się ich stad, można postępować $z$ żurawiami.

Intensywna gospodarka zwiazana $\mathrm{z}$ hodowla zwierzat powoduje wzrost zapotrzebowania na energię, a to $z$ kolei prowadzi do wyczerpywania naturalnych zasobów i skłania ludzi do poszukiwań alternatywnych, odnawialnych źródeł energii (woda geotermalna, wiatr, promieniowanie słoneczne, biomasa); jednak również one moga powodować zaburzenia funkcjonowania środowiska (SZCZERKOWSKA-MAJCHRZAK i GRZYBKOWSKA 2008). Alternatywą innego rodzaju niż energia odnawialna jest energia jądrowa, lecz ta ma zarówno wielu zwolenników, jak i przeciwników (AUSUBEL 2007); tych ostatnich przybyło po tragicznych w skutkach awariach powodujacych skażenia (np. zniszczona przez tsunami elektrownia Fukushima w Japonii) oraz w wyniku problemów ze składowaniem odpadów i likwidacja elektrowni po zakończeniu ich eksploatacji.

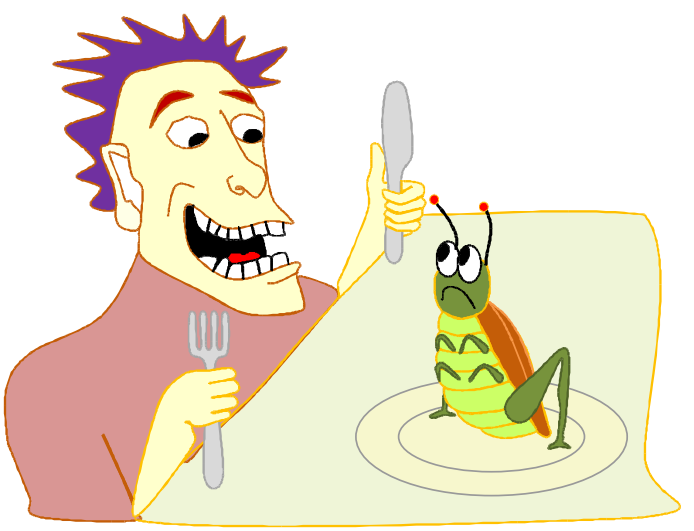

Ryc. 1. Wizja interakcji człowiek-owad. Czyż nie wygląda on smakowicie na talerzu? (rys. Łukasz \& Asia Głowacki).
W świetle powyższych okoliczności, nieustannie trwaja poszukiwania źródeł pożywienia nieobciążonych mankamentami, przede wszystkim energetycznymi. Alternatywa moga być owady (Ryc. 1). Mimo że przejście na dietę oparta na bezkręgowcach wymaga zmiany jadłospisu (zróżnicowanego w zależności od klimatu lub rejonu), a także ludzkich przyzwyczajeń, to mniejszy wpływ tych organizmów na dewastację przyrody i szereg innych wymienionych poniżej zalet stawiaja je zdecydowanie na pierwszym miejscu wśród konkurencyjnych źródeł pokarmu.

\section{OWADY POTENCJALNYM ŹRÓDŁEM BIAŁKA}

Entomofagia ma niewatpliwie wiele zalet. Przede wszystkim owady sa kaloryczne, w zakresie od 293 do $762 \mathrm{kcal} / 100 \mathrm{~g}$ (na podstawie analizy około 80 gatunków), co jest zdeterminowane wysoka zawartościa białka i tłuszczu w ich ciele (RAMOs-EloRDUY i współaut. 1997). Ponieważ zawartość energii zmienia się $\mathrm{w}$ rozwoju osobniczym owadów, szczególnie predestynowane sa larwy i poczwarki, energetycznie bogatsze niż formy dorosłe (imagines). Obok pełnowartościowego białka o wysokiej przyswajalności, owady zawieraja również liczne składniki mineralne, witaminy i nienasycone kwasy tłuszczowe (ARMitAGe i współaut. 1995, ZIELIŃSKA i współaut. 2018). Ponadto ekolodzy podkreślają kilkakrotnie niższe koszty uzyskania ich biomasy $\mathrm{w}$ porównaniu $\mathrm{z}$ powszechnie spożywanymi ssakami i ptakami oraz mniejsze zużycie paszy i wody.

Składowa pokarmu owadów moga stać się też, zazwyczaj trafiające do utylizacji, produkty uboczne przemysłu rolno-spożywczego, np. wytłoki, co z kolei stanowi dotychczas niestosowane rozwiazanie dla zagospodarowywania odpadów. Dodatkowo, odchody owadów sa cennym nawozem dla roślin. Hodowla owadów nosi miano przyjaznej dla środowiska, także ze względu na niska emisje gazów cieplarnianych (KRZYwiŃski i TOKARCZYK 2011, ZIELIŃSKA 2016). Ta niska emisyjność dotyczy większości owadów jadalnych (około 2000 tysięcy gatunków), chociaż są i wyjątki od tej reguły, np. termity, które przyczyniaja się do wytwarzania ogromnej ilości metanu (KePPLER i współaut. 2006, KREBS 2011).

Oczywiście hodowla dotyczyłaby larw owadów o stosunkowo dużej masie ciała, takich jak niektóre chrzaszcze, chruściki (Ryc. 2A, B) czy muchówki. Istnieją również imagines owadów o niewielkich rozmiarach, np. ochotki (Chironomidae, Diptera; Ryc. 2C), które sa konsumowane w różnych rejo- 

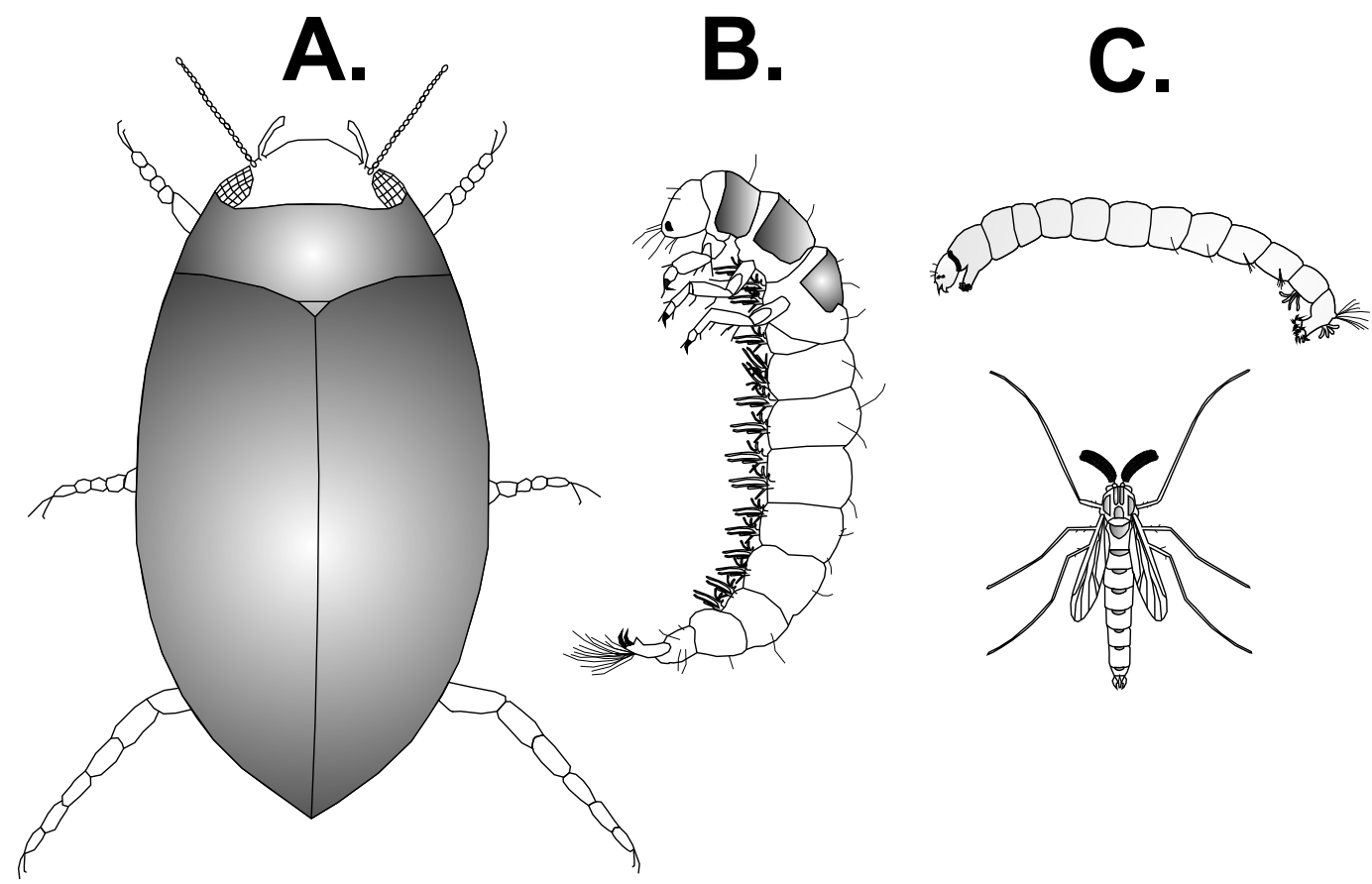

Ryc. 2. Rozmieszczenie chityny u owadów.

A) postać dorosła chrząszcza $z$ chitynowymi pokrywami; B) larwa chruścika z pogrubionymi chitynowymi tergitami na tułowiu; C) larwa i postać dorosła ochotek równomiernie pokryte chityną (rys. J. Leszczyńska, M. Grzybkowska).

nach świata, np. przez tubylczą ludność nad jeziorem Wiktorii. Masowo wylatujące owady, tworzace ogromne chmury w powietrzu (zwane rójkami), są przez ludzi łapane w siatki, wybierane $\mathrm{z}$ nich i zlepiane $\mathrm{w}$ płaskie ciasteczka, a nasteppnie gotowane. Owady te zawieraja dużo chityny; tubylcy traktuja je jak przysmak i z niecierpliwością czekaja na kolejne wyloty (GRZYBKOWSKA 2003).

\section{CZY ARGUMENTY PRZECIW KONSUMPCJI OWADÓW PRZEZ CZEOWIEKA SA ZASADNE?}

\section{WYMIERANIE OWADÓW - INSEKTAGEDON}

Jedną $z$ coraz częściej pojawiających się informacji $\mathrm{w}$ mediach jest zastraszajace tempo wymierania gatunków; $z$ kręgowców - płazów, a $z$ bezkręgowców - owadów (PTASZYŃSKA 2019). Za proces ten odpowiada człowiek, który poszukujacc żywności, surowców i energii bezlitośnie eksploatuje środowisko naturalne, niszczac np. tropikalne lasy, które sa tak istotne dla klimatu Ziemi. To również człowiek zanieczyszcza środowisko plastikiem i ściekami $z$ wysoka zawartościa metali ciężkich, rozpuszczalników czy innych toksycznych substancji oraz dokonuje innego rodzaju degradujących działań. Prawdopodobnie ich rezultatem jest w znacznej mierze to, że nisze ekologiczne opuszczone przez nieszkodliwe lub mało szkodliwe dla człowieka gatunki owadów zapełniane sa często przez gatunki bardzo niebezpieczne, które wbrew intencjom człowieka opanowuja coraz to nowe tereny. Przykładem jest szerszeń Vespa velutino, nazywany azjatyckim zabójca, o dużych rozmiarach i niezwykle silnym jadzie. Podobno pojawił się on już za zachodnio-południowymi granicami Polski. Gatunki proponowane do konsumpcji nie należą do grupy zagrożonych. W związku $\mathrm{z}$ tym ich konsumpcja nie spowoduje spadku bioróżnorodności owadów w rozmaitych środowiskach.

\section{OBECNOŚĆ CHITYNY W OWADACH}

Jedną $z$ wattpliwości, które rodzi perspektywa spożywania owadów przez człowieka jest także wysoka zawartość chityny w ich ciałach (GRZYBKOWSKA 2003, ZIELIŃSKA i współaut. 2018). Chityna (poliP-1,4-acetylo-D-glukozamina) jest homopolisacharydem, polimerem linearnym, który stanowi szkielet zewnętrzny nie tylko owadów, ale także innych stawonogów (skorupiaków), mięczaków, nicieni i pierwotniaków; obecna jest także w ścianie komórkowej wielu grzybów, okrzemek i bakterii. Chityna w postaci kutikuli wydzielana jest przez jednowarstwowy nabłonek pokrywajacy ciało organizmów bezkręgowych. Kutikula u niemal wszystkich stawonogów wysycona jest solami wapnia, dając w efekcie sztywne i trwałe elementy, tak niezbędne dla szkieletu zewnętrznego. Najgrub- 
sza kutikula występuje u skorupiaków, ale jej utwardzenie nie jest jednakowe na całej powierzchni; połaczenia między segmentami czy członami odnóży sa miękkie i elastyczne, co umożliwia organizmom przemieszczanie się. Ten pancerz jest cyklicznie zrzucany (linienie), aby możliwy był wzrost zwierzęcia. Należy przy tym pamiętać, iż także niektóre odcinki drożnych (o kształcie rur) narządów wewnętrznych, np. przewodu pokarmowego, maja zdolność wytwarzania chityny (GRZYBKOWSKA 2003).

Zanim zaczęto mówić o owadach jako o źródle białka, człowiek znalazł bardzo specyficzne zastosowanie dla sproszkowanej chityny. Substancja ta, ku zaskoczeniu wielu $\mathrm{z}$ nas, może pomóc człowiekowi w utrzymaniu prawidłowej masy ciała. Problem otyłości pojawił się $\mathrm{w}$ ostatnim stuleciu wraz ze swobodnym dostępem do pokarmu, coraz bardziej przetwarzanego i kalorycznego, przy równoczesnej zmianie trybu życia i zmniejszonym wydatkowaniu energii (brak wysiłku fizycznego, izolujace przed utrata ciepła ubrania, ogrzewane pomieszczenia itp.). Jak wiadomo zdolność do magazynowania energii w komórkach tkanki tłuszczowej (adipocytach) w formie tłuszczu, to reminiscencje odległej przeszłości. Cecha ta była wtedy niezwykle cenna dla przetrwania Homo sapiens, ale aktualnie jest bezużyteczna.

A obecnie? Jak podaje Światowa Organizacja Zdrowia (WHO 2018) kłopoty $z$ nadmiernym magazynowaniem tkanki tłuszczowej dotknęly wszystkie nacje, także Chińczyków, chociaż największe problemy $z$ nadwaga maja ludzie rasy czarnej, w tym Aborygeni i ciemnoskórzy Polinezyjczycy (NURKOWskA 1998). Konsekwencja otyłości są choroby, które $\mathrm{z}$ kolei generuja wydatki na leczenie. Praktyczni Amerykanie obliczyli, że koszty leczenia chorób zwiazanych $z$ otyłościa wynosza tyle samo, ile kosztuje łącznie walka z nowotworami i AIDS. Na całym świecie, także w Polsce, od lat trwaja zmagania lekarzy i naukowców $z$ nadwaga i otyłością. Najgrożniejsza jest otyłość brzuszna, która generuje cukrzycę, nadciśnienie czy stany przedrakowe. Początkowo $\mathrm{w}$ walce $\mathrm{z}$ otyłością duża nadzieję wiazano $z$ wprowadzeniem serotoniny (czynnik sytości), a później adrenaliny. Ponieważ dawkowanie tych medykamentów może być niebezpieczne ( $z$ różnych względów, także powodowania uzależnień) spróbowano odtłuszczać posiłki w jeszcze inny sposób - przy użyciu chityny lub chitosanu (deacetylowanej pochodnej chityny). Każdy z tych zwiazków w jelicie wiaże 12 razy tyle tłuszczu, ile sam waży (GRZYBKOWSKA 2003).

Chityna może także zastępować błonnik pokarmowy, w który nasza dieta jest $z$ natury uboga (KAYA i współaut. 2015). Jest ona głównie produktem ubocznym maki $z$ owadów i ma wiele innych zastosowań. Ze względu na degradowalność i nietoksyczność, chityna i chitosan sa przyjazne dla środowiska, dlatego znajduja zastosowanie w farmacji (wspomniane powyżej odchudzanie), medycynie [regulacja zawartości cholesterolu LDL (lipoproteiny niskiej gęstości) we krwi] i w przemyśle spożywczym (produkcja jadalnych biofilmów). Ponadto, chityna wykazała działanie przeciwutleniajace, przeciwbakteryjne i przeciwnowotworowe. Nie blokuje ona również rozdrabniania i wchłaniania pozostałych tkanek owadów, a wręcz przeciwnie, może ułatwiać ich przyswajanie. Związek ten i jego pochodne maja także zastosowanie $\mathrm{w}$ oczyszczaniu ścieków (ZIELIŃska i współaut. 2018).

Pozyskiwanie chityny nie sprawia kłopotów. Przede wszystkim producentami tego związku sa morskie skorupiaki: krewetki, kraby i homary - przedstawiciele dziesięcionogów (Decapoda). Ale nie tylko one. Wytwórcy chityny sa bardzo liczni w hydrosferze, zarówno w wodzie słonej, jak i słodkiej. Zainteresowanych tym zagadnieniem odsyłamy do literatury przedmiotu (CAUCHIE 2002).

Prawdziwa przeszkoda we wprowadzeniu owadów do masowej produkcji i przetwórstwa w przemyśle spożywczym jest brak, jak do tej pory, właściwych regulacji prawnych (VAN HUIS i współaut. 2013, ZIELIŃSKA 2016), zarówno w Polsce, jak i w wielu innych krajach.

\section{TRUDNOŚĆ ZMIANY NAWYKÓW ŻYWIENIOWYCH}

Najbardziej oporni na wprowadzanie owadów do jadłospisu sa Europejczycy, chociaż i wśród nich upodobania są zróżnicowane. W belgijskich sklepach można np. kupić potrawy przygotowane na bazie owadów, takie jak burgery i kotlety. Na rynku działa również wiele sklepów internetowych oferujacych produkty wytworzone, jeśli nie całkowicie, to częściowo $z$ owadów, takie jak np. batony, muesli, słodycze, makarony itp. Można też kupić mąkę $z$ owadów i samemu przygotować domowe posiłki (ZIELIŃSKA 2016). Istnieje zatem nadzieja, że również ci bardziej nieufni, pod wpływem rozmaitych dokumentów i raportów wydawanych między innymi przez agende Organizacji Narodów Zjednoczonych do spraw Wyżywienia i Rolnictwa (FAO), przekonaja się do spożywania owadów, przynajmniej jako dodatku do tradycyjnych potraw, co niekoniecznie musi się wiązać $z$ glęboka zmiana ich smaku i zapachu.

Przykładem takiego dokumentu jest raport $\mathrm{z}$ projektu o wartości $3 \mathrm{mln}$ złotych "Owady jako nowe źródło białka”, realizowanego w ramach programu FP7 (Research 
and Innovation Programme FP7). Zdaniem ZIELIŃSKIEJ i współaut. (2018), innowacyjne technologie produkcji białka i wzbogacania żywności w korzystne składniki pokarmowe pozwola na poprawę jego jakości, przy zachowaniu cech organoleptycznych pożądanych przez konsumentów. Poprzez przełamywanie stereotypów, przekazywanie rzetelnych informacji i uświadamianie społeczeństwu konieczności wprowadzenia zmian w zwyczajach żywieniowych, możliwe będzie właściwe rozwiazanie, chociażby na jakiś czas, problemu braku białka na świecie, a tym samym ochrony naszej planety przed dalsza degradacja.

\section{Streszczenie}

Nasilający się przez kilkadziesiąt ostatnich lat wpływ człowieka na Ziemię prowadzi do degradacji środowiska. Okres ten nazwano zatem antropocenem. Obecnie żyjemy w jego trzeciej fazie, określanej Wielkim Przyśpieszeniem.. Głównymi czynnikami sprawczymi tej degradacji jest liczebny wzrost populacji ludzkiej i potrzeba zaspokajania jej wymagań. Prowadza one do niedoborów energii i pożywienia, którym przeciwdziałać moga nowe, odnawialne źródła energii (wiatr, promieniowanie słoneczne, woda geotermalna, biomasa i rozszczepianie ato$\mathrm{mu}$ ) oraz pożywienie $\mathrm{w}$ postaci owadów. Owady sa nie tylko cennym źródłem białka, lecz także, w farmakologii związanej $z$ odżywianiem, źródłem chityny i jej deacetylenowej pochodnej, chitosanu, które absorbuja w przewodzie pokarmowym człowieka 12 razy więcej thuszczu niż same waża. Poza tym, zwiazki te reguluja zawartość cholesterolu LDL we krwi oraz moga działać podobnie do błonnika zawartego $\mathrm{w}$ innych pokarmach. Owady wymagaja o wiele mniej pokarmu i wody do budowy ciała niż zwierzęta kręgowe i rośliny. Opory wielu europejskich narodów przy spożywaniu owadów sa mniejsze, gdy pokarm $z$ tych zwierzat jest wysoko przetworzony.

\section{LITERATURA}

Armitage P. D., Cranston P. S., Pinder L. C. V., 1995. The Chironomidae. The biology and ecology of non-biting midges. Chapman \& Hall, London.

Ausubel J. H., 2007. Renewable and nuclear heresies. Int. J. Nucl. Govern. Econom. Ecol. 1, 229-243.

BIŃCZYK E., 2017. Dyskursy antropocenu a marazm środowiskowy poczatków XXI wieku. Zeszyty Naukowe Politechniki Śląskiej. Seria: Organizacja i Zarzadzanie 112, 47-59.

CAVES C., 2016. Czy ludzkość przetrwa kolejnych 500 lat? Świat Nauki 10, 62.

CAUCHIE H. M., 2002. Chitin production by arthropods in the hydrosphere. Hydrobiologia 470, 63-96.

CRutzen P., Stoermer E. F., 2000. The 'Anthropocene'. Global Change Newslett. 41, 17-18.

DURANDO J., 2015. Holy cow! Meat eaters consume 7,000 animals in lifetime. http://eu.usatoday. com/story/news / nation-now/2015/03/11/ meat-eaters-animals-lifetime/70136010/.

GrINSPOON D., 2016. Nieśmiertelna cywilizacja. Czy uda nam się uniknać wymarcia? Swiat Nauki 10, 62 .
GRZYBKOWSKA M., 2003. Czy skorupiaki $i$ owady pomoga nam schudnaç? Wszechświat 104, 29-31.

GRZYBKOWSKA M., LESZCZYŃSKA J., 2019. Jak żyć $w$ antropocenie bez krzywdy dla siebie $i$ planety? Nauka Przyr. Technol. 13, 89-99.

KAYA M., ERDOGAN S., MOL A., BARAN T., 2015. Comparison of chitin structures isolated from seven Orthoptera species. Int. J. Biol. Macromol. 72, 797-805.

KePPleR F., Hamilton J. T., BRAss M., RÖCKMANN T., 2006. Methane emissions from terrestrial plants under aerobic conditions. Nature 439, $187-191$.

KREBS C. J., 2011. Ekologia. Eksperymentalna analiza rozmieszczenia $i$ liczebności. Wydanie 4. PWN, Warszawa.

KRZYWIŃSKI T., TOKARCZYK G., 2011. Owady - źródło ekologicznego białka. Przemysł Spożywczy 65, 34-38.

KundZEWICZ Z. W., JUdA-REZLER K., 2010. Zagrożenia zwiazane ze zmianami klimatu. Nauka 4, 69-76.

NURKOWSKA J., 1998. Problem $w$ skali XXL. http:/ / archiwum.wiz.pl/1998/98102600.asp.

PTASZYŃSKA A. A., 2019. Antropocen, wielkie przyspieszenie $i$ insektagedon. Kosmos 68, 553560.

Ramos-Elorduy J., Moreno J. M. P., Prado E. E., Perez M. A., Otero J. L., De Guevara O. L., 1997. Nutritional value of edible insects from the state of Oaxaca, Mexico. J. Food Compos. Anal. 10, 142-157.

SiENKIEWICZ J., 2013. Ochrona różnorodności biologicznej $w$ krajach UE do 2020 r. - nowa strategia europejska. Pol. J. Agronom. 14, 45-62.

SZCZERKOWSKA-MAJCHRZAK E., GRZYBKOWSKA M., 2008. Pietrzenia rzek i energia wodna; za i przeciw. Kosmos 57, 295-303.

WHO, 2018. http://www.who.int/en/news-room/ fact-sheets/detail/obesity-and-overweight.

WilletT W., ROCKSTRÖM J., LOKEN B., SPRINGMANN M., Lang T., Vermeulen S., GarnetT T., TILMAN D., DECleRCK F., WOOD A., JONELl M., Clark M., Gordon L. J., FANZO J., Hawkes C., Zurayk R., Rivera J. A., De VRIES W., SiBANDA L. M., AFSHIN A., CHAUDHARY A., HERRERO M., Agustina R., BRANCA F., LARTEy A., Fan S., Crona B., FoX E., Bignet V., Troell M., Lindahl T., Singh S., CORNEll S. E., REDDY K. S., NARAIN S., NISHTAR S., MURRAY C. J. L., 2019. Food in the Anthropocene: the EAT-Lancet Commission on healthy diets from sustainable food systems. Lancet 393, 447492.

Van Huis A., Van ItTerbeeck J., Klunder H., MERTEns E., Halloran A., Muir G., VANTOMME P., 2013. Edible insects: future prospects for food and feed security. FAO Forestry $\mathrm{Pa}-$ per, Rome.

ZALASIEWICZ J., 2016. Warstwy historii. Ludzki ślad na Ziemi. Świat Nauki 10, 22-29.

ZIELIŃSKA E., 2016. Perspektywy spożycia owadów przez Europejczyków. Nauki Przyrodnicze $2,12-19$.

ZIELIN̂SKA E., KARAŚ M., JAKUBCZYK A., ZIELIŃSKI D., BARANIAK B., 2018. Edible insects as source of proteins. [W:] Bioactive Molecules in Food. MÉRILlON J.-M., RAMAWAT K. G. (red.). Springer International Publishing $\mathrm{AG}, \mathrm{Ba}-$ sel, 1-53. 
KOSMOS Vol. 69, 2, 355-360, 2020

\section{MARIA GRZYBKOWSKa, JoANNA LESZCZYŃSKA, ŁUKASZ GŁOWACKI}

Department of Ecology and Vertebrate Zoology, Faculty of Biology and Environmental Protection, University of Lodz, 12/16 Banacha Str., 90-237 tódź, e-mail: maria.grzybkowska@biol.uni.lodz.pl

\section{PROS AND CONS OF INSECTS ON A PLATE}

\section{Summary}

The influence of man on Earth, which has intensified over the past few decades, leads to environmental degradation. This time period is named the Anthropocene. We are now experiencing its third phase, the Great Acceleration. The causes of the degradation are overpopulation and necessity of satisfying human needs. They lead to energy and food shortages, which may be remedied by new, renewable energy sources (wind, solar radiation, geothermal water, biomass and nuclear fission) and food from insects. Insects are not only a rich source of proteins but also of chitin and its deacetylation derivative, chitosan, which bind 12 times more fat than they themselves weigh. They also help to control the level of LDL cholesterol in blood, and may act similarly to fiber in other food types. Insects require much less forage and water for producing their body than vertebrate animals and plants. The aversion of many European nations to the consumption of insects is much reduced when insect food is highly processed.

Key words: anthropocene, diet modification, food from invertebrates, overpopulation, protein 